During the long era of David Morse (1948-1970), the International Labour Organization (ILO) underwent a profound transformation. The Cold War and decolonization were the two main drivers behind this process, which changed the ILO's face and its internal power balance and left hardly any area of its work untouched. The year 1954 proved to be an important milestone in this regard. One year after Stalin's death, the Soviet Union took up its membership again. As a result, the ILO no longer occupied the status of a quasi-front organization in the Western camp. ${ }^{399}$ While this change "normalized" the ILO's position within the UN system, fundamental controversies now reappeared directly on the agenda, including the question of the ILO's tripartite composition. The confrontation with the alternative social model of the communist bloc forced the ILO to continuously examine its foundations and search for a workable balance between the quest for universalism and conflicting ideas of social organization. ${ }^{400}$

At the same time, during the "Morse era", the ILO underwent another transformation that was at least as drastic. As a result of the accelerated dissolution of the European colonial empires in Asia and Africa, it gained more than twice the number of member States within a period of two decades - from 55 countries in 1948 to 121 in 1970. This growth in membership was almost exclusively accounted for by former colonies. ${ }^{401}$ From the 1960 s onwards, "developing countries” formed a majority of the ILO's member States. This was a strong incentive for the Organization to adapt its profile, policies, and programmes to the needs and demands of these countries. It pushed the ILO to further expand its technical functions and to place an evermore pronounced emphasis on development. On another level, decolonization contributed to the further "politicization" of the ILO's meetings. The struggle of the new nations against the last remnants of colonial rule and racist regimes in Southern Africa hit the Organization during the 1950s and the 1960s with full force.

The dynamics that drove the ILO during this period resulted to a large degree from the entanglement and overlap of Cold War and decolonization debates. This became most apparent in the area of standard-setting, where human rights

399 Together with the Soviet Union, the Soviet Republics of Ukraine and Byelorussia were admitted as independent members in accordance with the UN formula in place, which strengthened the position of the Eastern bloc. Morse's negotiations with the Soviet leaders are recorded in ILOA MF Z 5/1/64/1, Re-admission USSR, 1954, 1961. See also Cox, "ILO-Limited Monarchy”, 105-106.

400 Daniel Roger Maul, “The 'Morse Years': The ILO 1948-1970”, in ILO Histories, ed. Van Daele et al., 365-400.

401 Ghébali, The International Labour Organization, 119-120

Ә Open Access. (c) 2019 International Labour Organization, published by De Gruyter and the ILO. (c) BY-NC-ND

This work is licensed under a Creative Commons Attribution-NonCommercial-NoDerivatives 4.0 
issues assumed a prominent role particularly during the 1950s. In the discussions about the adoption and implementation of standards on freedom of association, forced labour, and discrimination, initial controversies along the EastWest divide increasingly developed into parallel debates along the conflict line between the industrial nations of the West and an emerging group of countries from the global South. 



\section{The Development Turn}

With the expansion of its technical assistance, the massive changes that the ILO underwent as a result of decolonization became very tangible. After moderate beginnings in the 1950s, the area that became known as "technical cooperation" outgrew during the 1960s and 1970s all other areas by far. At the same time, the ILO's move from limited technical assistance to large-scale technical cooperation affected virtually all the ILO's fields of action. By turning into an agency of technical cooperation, the ILO eventually lost its European bias. The Organization took on a much more global face, and its operational efforts became more and more directed towards the needs of less industrialized countries.

To be sure, the ILO did not pursue this transition in isolation. Just like other international agencies at the time, it acted as a part of the United Nations' growing development machinery. ${ }^{402}$ At the same time, driven by strategic considerations, by its constituents and by inter-agency competition, the ILO sought to develop its own profile. Two major programmes serve to illustrate this point: the Andean Indian Programme (AIP) of the 1950s and 1960s, and the World Employment Programme (WEP) launched on the occasion of the ILO's 50th anniversary in 1969. Both programmes reflected general trends in development thinking at the time. Through the WEP, in particular, the ILO took a lead in this discussion and was instrumental for a short-lived - but nevertheless major - turn in development thinking towards poverty-centred approaches during the 1970s.

\section{Help Them Move the ILO Way - Technical Assistance in the 1950s}

When the ILO's technical assistance activities began to take off in the early 1950s, they essentially consisted of building labour force capacities by means of vocational training or projects aimed at raising workers' productivity. During the 1950s, the working area of "human resources" accordingly occupied around 75\% of all Tech-

402 Corinna R. Unger, International Development. A Post-War History (London: Bloomsbury Academic Publishing, 2018); Frey, Kunkel, and Unger, "Introduction: International Organizations, Global Development, and the Making of the Contemporary World”; Richard Jolly et al., UN Contributions to Development Thinking and Practice, United Nations Intellectual History Project (Bloomington, IN: Indiana University Press, 2004). 
nical Assistance Programmes (TAP). ${ }^{403}$ Vocational training schemes alone, with a clear direction to support developing countries' efforts towards industrialization, accounted for around half of the ILO's technical assistance activities in this period..$^{404}$ Even in the 1960s, when the ILO's programmes underwent a substantial reform, and services stretched more widely to include agriculture and fields like workers' education and management training, the development of "human resources", with vocational training at its core, remained at the heart of technical cooperation. ${ }^{405}$

The early TAP's heavy industrial bias can easily be explained by the general context of its beginnings. Originally the departure into technical assistance had been an extension of the 1948 Manpower Programme, tailored to the needs of war-torn Europe and focused on industrial training. ${ }^{406}$ The relative insignificance of rural development, in turn, had to do with the fact that agricultural training was the prerogative of the FAO, which was also funded through the United Nations' EPTA. In general, however, the industrial focus simply reflected the prevailing view of development policy. Within the "dualistic" approach of a first generation of development economists like W. Arthur Lewis, the central dynamic of development was a movement of underdeveloped societies from the traditional to the modern, or industrial, sector. Only the latter could lead to productivity and growth and thus to an improvement in the standard of living. ${ }^{407}$ The task of development agencies, both national and international, was to support and accelerate such a modernization process. The TAP's focus on "manpower" fits perfectly with the dualistic vision. The general opinion was that through training workers the ILO contributed significantly to industrialization and increased productivity. ${ }^{408}$

The new programmatic orientation was accompanied by substantial changes on the level of the International Labour Office, where staff became more diverse, both in terms of expertise and geographical distribution. Recruitment strategies had already started to change under Harold Butler in the 1930s, and this change accelerated as a

403 The other areas were "living conditions" and "social institutions". The latter included also the ILO's activities in the field of cooperatives. On the evolution of the ILO's Technical Assistance Programme, see Ghébali, The International Labour Organisation, 242-267.

404 ILO, "The Role of the ILO in the Promotion of Economic Expansion and Social Progress in Developing Countries” (Geneva: ILO, 1961); ILO, A Great Adventure of our Time. International Co-operation and the ILO (Geneva: ILO, 1962), 36.

405 The Governing Body confirmed in 1965 that all the ILO's technical activities would fall under the three main headings of (1) human resources, (2) development of social institutions, and (3) improvement of working and living conditions.

406 See, e.g.: “The I.L.O. Manpower Programme”, International Labour Review, 59, no. 4 (April 1949): 367-393.

407 Unger, International Development, 109.

408 Ibid., 70-71. 
result of the extended economic mandate the ILO had received in Philadelphia: economists and social scientists started to represent a much larger proportion of the ILO's staff. The sheer quantity of operations in the 1950s drove another change. While the technical assistance missions of the interwar period had been conducted mostly by ILO officials, the Organization now relied to a much greater degree on the services of external experts. Between 1950 and 1965, the ILO sent almost 2,000 experts from a total of 78 nations on 3,000 expert missions to around 100 countries. $^{409}$

Moreover, the geographical composition of the International Labour Office underwent significant change. Under Morse, senior posts were filled with nationals from Asian and African countries. One prominent example was Abbas Amar, a former Egyptian Minister of Education and of Social Affairs. He was recruited by Morse and occupied the post of Assistant Director-General from 1959 to 1974. Albert Tévoédjrè, a former Minister of Information from Dahomey (Benin), would follow in 1965 as the first member in the Director-General's Office from sub-Saharan Africa. ${ }^{410}$ On another level, technical assistance also contributed to the further geographical decentralization of the ILO. Between 1949 and 1952, field offices were set up in Asia (Bangalore), Latin America (Sao Paulo), and, for the Middle East, Istanbul. In sub-Saharan Africa, which was still under colonial rule, the establishment of ILO regional representation took longer. Fears among colonial officials that such an office would turn into a centre of "agitation" and open the door for an "internationalization" of colonial affairs prevented the ILO for a long time from gaining a foothold on the African continent. Only in 1959, on the eve of the independence of numerous African countries, was the Organization able to open its first African field office in Lagos, Nigeria. ${ }^{411}$ The main task of the field offices was to facilitate the coordination of technical assistance in their respective regions. This process of dispersal continued into the 1960s, with further decentralization of the ILO. Between 1965 and 1968, the field offices became area offices, which were in turn placed under newly founded Regional Offices, assuming responsibility for all the ILO technical cooperation programmes and projects in a particular region. ${ }^{412}$

Finally, the new activities also affected the ILO's budget. While the initial fears that technical assistance might become the gateway for American domina-

409 Ghébali, The International Labour Organisation, 256.

410 Oral History Interview with David Morse, Oral History Research Office, Columbia University 1981, conducted by Peter Jessup, Columbia University, in Washington, D.C., July 1980-March 1981, 122-123. 411 Maul, Puddu, and Tijani, “The International Labour Organization”. For a general overview, see also Nicholas Alexander Bernards, "Actors and Entanglements in Global Governance: The ILO in Sub-Saharan Africa” (PhD diss., McMaster University, Hamilton, ON, 2016).

412 Ghébali, The International Labour Organisation, 162; Alcock, History of the International Labor Organization, 239, 240. 
tion of the ILO soon dissipated, new dependencies arose in other areas. Through the EPTA and the so-called Special Fund - another UN source of funding set up in 1958 for the purpose of facilitating larger projects - the ILO now had access to extra-budgetary sources. At the same time, it increased the ILO's reliance on the United Nations, notably on ECOSOC, which managed these funds. This dependency became even more pronounced when the United Nations Development Programme (UNDP) was established in 1965. Under the EPTA, the funds available in the 1950s had generally fallen short of enabling the ILO to meet all the requests it received for technical assistance. ${ }^{413}$ With the establishment of the UNDP, this changed; funds could now be obtained for longer-term development programmes, which opened up entirely new opportunities for projects that could not be financed through the ILO's regular budget. At the same time, however, the ILO lost a considerable degree of independence, as an increasing proportion of ILO work eluded the financial oversight of the Governing Body, which had few opportunities to influence the UNDP's criteria for awarding funds. ${ }^{414}$

Dependence on UN development policy premises was a weighty, if not the sole, reason why the ILO was keen from the outset to put its own recognizable signature to its technical activities. The TAP rested on a series of basic principles and ILOspecific assumptions that also determined its form. For the architects of the TAP, it was above all necessary to counter concerns that the new field of development policy would push the "classical" standard-setting activities into the background and thus to dilute the ILO's core identity. To dispel these widespread concerns, David Morse started as early as 1949 to promote an ILO-specific integrated approach to development. Technical assistance and ILO standards were not seen as opposing principles but as concepts that had a catalytic and mutually beneficial effect. ${ }^{415}$ The operational activities on which the ILO was about to embark were, with regard to standard-setting, "the other half of the same coin", as the new Director-General told the ILC in 1949. Their purpose was, according to Morse, to trigger and sustain a process of development in line with the aims of the ILO Constitution. ${ }^{416}$

413 Among the different recipients of the funds of the United Nations' technical assistance programme, the ILO was only fourth in line, receiving only $11 \%$ of the EPTA budget and trailing organizations such as UNESCO, WHO, and FAO. In absolute numbers, the ILO was given just over US $\$ 25$ million between 1950 and 1960 under the EPTA, while the FAO received US\$68 million, the WHO US\$45 million, and UNESCO US\$35 million. ILO, The Role of the ILO in the Promotion of Economic Growth (Geneva: ILO, 1961), 7.

414 Hugo Stokke, "Decent Work. Principles, Policies and Programmes of the International Labour Organisation” (PhD diss., University of Bergen, 2015), 136-144.

415 See Alcock, History of the International Labor Organization, 219.

416 Ibid., 259. 
Such assurances were also meant to dilute more general concerns that the ILO, through the TAP, might turn further into an organization primarily following an economic rationale. Morse's emphasis on "productivity" initially fuelled these concerns. ${ }^{417}$ Wedded as the concept of productivity was to American ideas of economic progress, it met a fair degree of suspicion, in particular from the trade unions. In 1952, Morse explained that, from his point of view, raising productivity in all economic sectors was the only practicable route to development. But he underlined that the ILO's approach to productivity differed from that of other development agencies by recognizing that increased productivity alone did not guarantee social progress. Morse promoted a three-pronged approach that took into account "the educational, the social and the technical sides" of the issue. He pledged that, for the ILO, promoting increased productivity would lead rapidly to improvements in economic and social welfare for the community in general. Governments, he affirmed, would consider good industrial relations and satisfactory wages and employment policies not merely as accessory measures but as "integral parts of programmes to raise productivity". ${ }^{418}$

Underlying the TAP was the basic assumption of modernization theory that the developing world had to repeat, in accelerated form, the development of industrialized countries. ${ }^{419}$ "There [is] nothing peculiar to this region", Morse told a press conference on the occasion of the Asian Regional Conference in Delhi in 1957: "Asia and India [are] going through a process of economic expansion and development that Western countries [were going] through long ago." The challenges that they faced as a result of this process were "new in Asia, but old problems in other countries". ${ }^{420}$ In this sense, the ILO's international labour standards, its Constitution, and the principles of the Declaration of Philadelphia featured as tools for democratic modernization in the global South. These standards and values were interpreted and promoted in practice as a set of lessons which the liberal democracies of Europe and North America had learned from past political and economic crises, which were linked to the development of their

417 For the debate and Morse's reply, see ILC (1949), Record of Proceedings, 25-254, 255-264.

418 Memorandum by Morse, "Memorandum on the Report of the Director-General to the 34th Session of the International Labour Conference”, quoted in Maul, Human Rights, Development and Decolonization, 135.

419 On the political implications of modernization theory, see Michael E. Latham, Modernization as Ideology: American Social Science and "Nation Building" in the Kennedy Era (Chapel Hill, NC: University of North Carolina Press, 2000); Nils Gilman, Mandarins of the Future: Modernization Theory in Cold War America (Baltimore, MD: Johns Hopkins University Press, 2003).

420 Minutes of a press conference held by Morse in New Delhi, 12 November 1957, quoted in Maul, Human Rights, Development and Decolonization, 138. 
own capitalist order in the nineteenth and twentieth centuries. The historic role of the Organization in this endeavour was described by Morse in quasi-religious terms: "If it does this the ILO will light a beacon which will guide men and women through the uncertain times which lie ahead and give to those whose hearts and minds are troubled, confused and afraid a positive faith by which they can work and live and a belief in themselves and in their future which will be proof against attacks from any quarter." 421

It was thus clear that entering the field of development was by no means a politically neutral undertaking. It gave the ILO a key role on one of the major front lines of the Cold War which were expanding rapidly beyond Europe to the developing world. "Change and revolution are sweeping the world today”, Morse wrote in 1950, and the ILO was caught up in a "struggle for the hearts and minds of men and women the world over". ${ }^{422}$ Social unrest and instability caused by rapid modernization, Morse argued, were breeding grounds for communist agitation. To Morse, the core values of the Declaration of Philadelphia - which combined the subordination of all national and international policies to the higher aim of social justice for everybody with a "fundamental view of society, of morality and of the freedom and dignity of the individual" - were the tools to counter this challenge. ${ }^{423}$ The Cold War undertones of technical assistance were thus part and parcel of its very beginnings. After the Soviet Union resumed its membership in the ILO in 1954, the statements accompanying technical assistance became less confrontational. Yet, what remained unchanged was the persistent claim that the ILO represented a particular "integrated" model of development that was of liberal-democratic nature at its core.

During the 1950s, ILO officials went out to promote this approach with almost missionary zeal. On his return from Egypt in 1953, Deputy Director-General Jef Rens maintained that the changes taking place there and in other countries in transition should spur the ILO on to assert its approach in the rapidly advancing process of economic development: "This part of the world and similar areas are moving - that's certain", Rens stated. "Let's not miss the chance to help them move the ILO way." 424

The ways in which the Office went about promoting the "ILO way" of development remained nevertheless - not least due to a lack of funding - fairly

421 Memorandum by Morse, "Memorandum on the Report of the Director-General to the 34th Session of the International Labour Conference”, quoted in Maul, Human Rights, Development and Decolonization, 139.

422 Ibid.

423 Ibid.

424 Quoted in Maul, Human Rights, Development and Decolonization, 139. 
small-scale and indirect. The Organization provided information, advice, and practical support, for instance, on how to set up a vocational training centre in a specific area, and how to educate local trainers and supervise the creation of vocational training institutions in the recipient countries. ILO experts gave advice on occupational health and safety as well as on the establishment of "healthy" labour relations, and they provided manuals teaching how to write standard employment contracts or formulate reasonable wage policies. ${ }^{425}$ ILO projects tended to be small, isolated, selective, and short-term. In Indonesia, in 1956, an ILO expert was assigned to carrying out a study to determine various aspects of the workforce for the Ministry of Labour. In Pakistan, ILO experts were supporting staff at the ministry to conduct enquiries on employment and potential future demand. The ILO was assisting the establishment of vocational training centres in countries like (South) Vietnam, Burma, Libya, Egypt, and Nepal. ${ }^{426}$

The experts who were deployed to provide assistance naturally played an important role in the implementation of the programme. Short introductory seminars before their departure familiarized them with the objectives and principles of the ILO, but it is difficult to determine to which extent these experts really internalized the integrated approach to development and put it into practice. The same can be said of the other method of knowledge transfer used in the early stages of the TAP, which was based on education. The ILO awarded study grants and arranged for a large number of people from developing countries ranging from skilled workers to future employees in labour administrations - to visit industrialized countries for on-the-job training or further education. All these projects relied on the assumption that industrial development would create the workplaces where the newly acquired skills and knowledge would be used.

With the growing scale of activities, a great majority of experts sent to the field were not ILO staff but recruited from outside the Organization on the basis of an earlier career in the required field. This raised a plethora of new and sometimes politically explosive issues: from the use of former colonial officials to charges of

425 The limited funding available to the ILO in the 1950s necessarily impacted on the efficacy of the Organization's campaign. A typical example was a project in Libya, where the ILO set up a vocational education centre; in Iran where the ILO built a specialized vocational training centre for the building trade; or India where several small-scale projects aimed at raising productivity in selected enterprises of the textile and engineering industry. See ILO, The Role of the ILO in the Promotion of Economic Growth.

426 ILO, The ILO and Asia (Geneva: ILO,1962); ILO, The ILO and Africa (Geneva: ILO, 1960). 
favouring Western experts over those from Eastern communist countries to recurring issues of geographical balance. ${ }^{427}$

An important step on the institutional level in this regard was the founding of the International Institute for Labour Studies (IILS) in 1960, ${ }^{428}$ an autonomous body within the Office for research and training that would focus on the sociopolitical problems faced by the developing world. In particular, it wanted to establish a working environment in which controversial topics such as industrial relations could be discussed apart from the politically charged atmosphere of the ILC. Its main purpose, next to research, was "educational action". IILS courses were directed at "potential leaders" from the developing countries' social sector, as Robert Cox, one of the Institute's first directors, explained. The courses on offer covered a wide range of areas, from employment issues to industrial relations. According to the Institute's vision, however, it served a broader purpose: the world's future policy makers would go to Geneva, encounter the methods and principles of the ILO, and take them back to their home countries. ${ }^{429}$

In 1964, the ILO set up an International Centre for Advanced Technical and Vocational Training in Turin, thus increasing its range of services on the institutional level. ${ }^{430}$ The courses offered at the Centre were directed first and foremost at skilled workers, vocational trainers, and management personnel from developing countries. The new Centre thus institutionalized an existing area of work, but, once again, with the added advantage that its visitors could be given a thorough grounding in the goals of the ILO. ${ }^{431}$ "In the last analysis", Morse wrote in this regard as early as 1959, "the most and perhaps only effective answer to communism and other antidemocratic forms lies in the success of social and economic development complemented with education and training in all of its aspects". ${ }^{432}$ Viewed from another perspective, the establishment of the IILS and the Turin Centre were part of a broader trend towards professionalization, driven by the per-

427 For the general debate about the colonial legacy of developmental expertise, see Joseph Morgan Hodge, The Triumph of the Expert. Agrarian Doctrines of Development and the Legacies of British Colonialism (Athens, OH: Ohio University Press, 2007).

428 Maryse Gaudier, “The International Institute for Labour Studies: Its Research Function, Activities and Publications 1960-2001,” Geneva: ILO, 2001.

429 Memorandum by Robert Cox, “Aims and Purposes of the IILS”, 15 July 1965, quoted in Maul, Human Rights, Development and Decolonization, 256; See also a more comprehensive analysis of the IILS functions Robert Cox, "Education for Development”, International Organization 23, no. 1 (1968): 310-331.

430 The opening was made possible by a grant from the Italian government, which offered the premises of the Italia 61 exhibition built on the occasion of the centenary of Italian unity in 1961. 431 Ghébali, The International Labour Organisation, 258.

432 Quoted in Maul, Human Rights, Development and Decolonization, 223. 


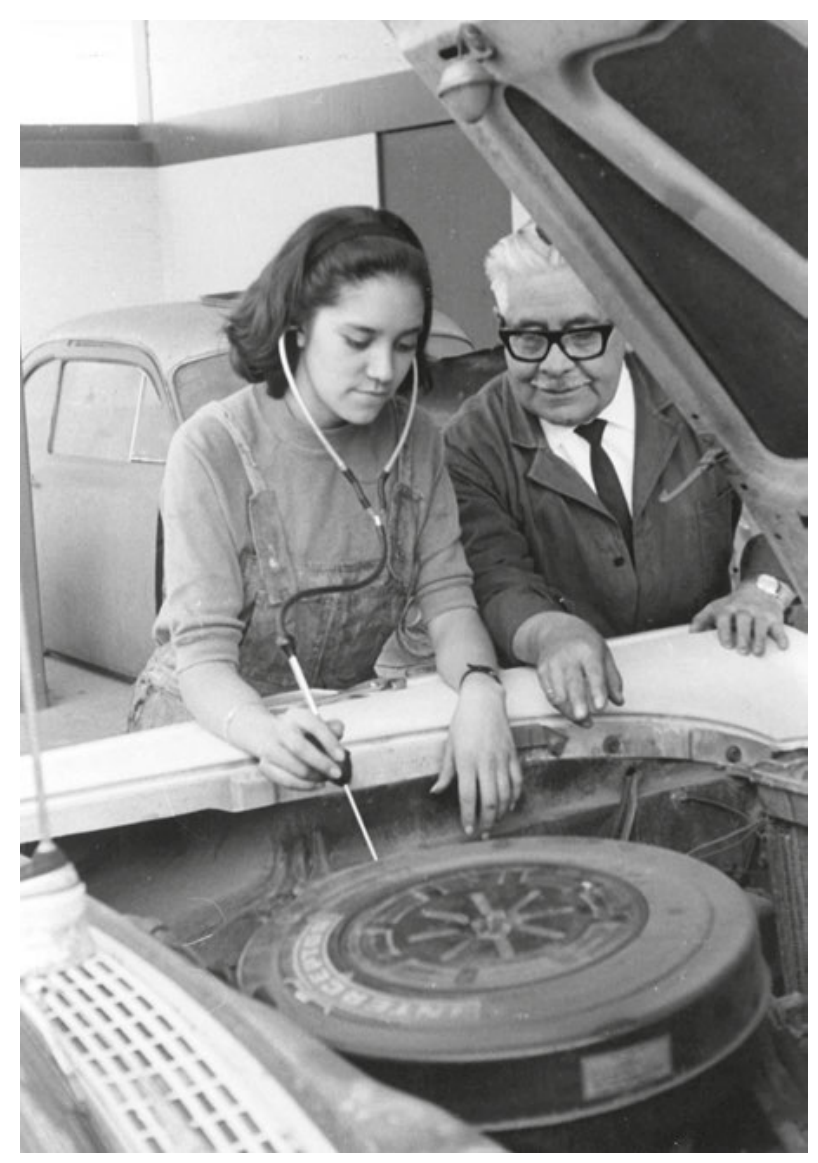

Figure 9: Training course in car mechanics, International Training Centre of the ILO, Turin, 1960 s.

ception that "more scientific" approaches were necessary to gain credibility, both with the public and vis-à-vis other organizations carrying out similar functions. ${ }^{433}$

\section{Indigenous Labour and the Andean Indian Programme}

While much of the ILO's technical work way until the 1960s was of rather limited scope due to the lack of funding, the new working area of "indigenous labour" paved the way to a broader vision of modernization beyond development. Here, an entirely new field opened up for the ILO after 1945, including both technical

433 Unger, International Development, 74-75. 
assistance and standard-setting. While the “Andean Indian Program” (1953-1962) provided the framework for one of the ILO's largest development aid project of all times, two Conventions on indigenous populations (1957) and on indigenous peoples (1989) were pioneering instruments that made indigenous peoples and their rights, for the first time, a subject of international law. ${ }^{434}$

The original interest of the ILO for the concerns of indigenous peoples resulted from the opening of the Organization towards Latin America in the late 1930s. Until then, the term "indigenous labour" (or native labour) had almost exclusively been used with colonial connotations. The living conditions of indigenous peoples as culturally identifiable groups within independent states had not yet caught the attention of the ILO. At the ILO's first two American Regional Conferences in Santiago de Chile (1936) and Havana (1939), ILO officials came into contact with the continent-wide political and academic movement of "indigenismo", which promoted the "uplifting" and ultimately assimilation of indigenous populations with their respective national societies. In Santiago, the ILO had already been urged to pay special attention to the economic and social problems of indigenous populations. Through its subsequent collaboration with indigenist institutions such as the Instituto Indigenista Interamericano in Mexico City, the ILO soon gained a reputation of being the "International Indigenist Organization". Thus, the "Indian problem" had already become an integral part of the ILO agenda well before the Second World War. After 1945, it turned into a priority of the ILO's regional work in Latin America. ${ }^{435}$

Equipped with new opportunities for socio-economic and development action after 1945, the ILO received a mandate from the American Regional Conferences in Mexico City (1946) and Montevideo (1949) to set up an Indigenous Labour Programme. Deputy Director-General Jef Rens, who oversaw the ILO's technical assistance activities at the Office level, and the Argentine economist and anthropologist David Efron became the main persons responsible for the move of the ILO into the area of indigenous labour. The establishment of a Committee of Experts on Indigenous Labour, chaired by renowned New Zealand anthropologist Ernest Beaglehole, initiated the practical phase of the indigenous labour programme in 1950. A report entitled "Indigenous Peoples: Living and Working Conditions of Aboriginal Population in Independent Countries" was the most important outcome of the Committee's two meetings in La Paz (1951) and Geneva

434 Indigenous and Tribal Populations Convention, 1957 (No. 107) and the Indigenous and Tribal Peoples Convention, 1989 (No. 169). Luis Rodríguez-Piñero, Indigenous Peoples; Hanne Hagtvedt Vik, “Indigenous Internationalism”, in Internationalisms: A Twentieth Century History, ed. Sluga and Clavin, 315-339. Cambridge: Cambridge University Press, 2017. Jason Guthrie, “The ILO and the International Technocratic Class, 1944-1966”, in Globalizing Social Rights, ed. Kott and Droux, 115-136. 435 Rodríguez-Piñero, Indigenous Peoples, 53-112. 
(1954). It included a set of guidelines for the gradual integration of indigenous groups into "modern" society under a broad development policy premise, as well as measures to attenuate this process from an anthropological point of view. ${ }^{436}$

The undisputed centrepiece of all activities was the Andean Programme (also known as the Andean Indian Programme, AIP), which was officially launched in 1953. After becoming part of the EPTA, the ILO was given the lead by the ECOSOC to prepare the ground - together with WHO, UNESCO, FAO, and the Organization of American States (OAS) - for a tailor-made development project in the three Andean countries of Bolivia, Ecuador, and Peru, which had a high proportion of indigenous populations. ${ }^{437}$ The AIP consisted of three phases. During the first phase, so-called action bases were set up in selected locations in all three countries that would serve as pilot projects for the expansion of the programme in the second phase. During the third and final phase, the programmes were to be transferred to the respective national governments, while, at the same time, the AIP was to be extended to other countries in the region.

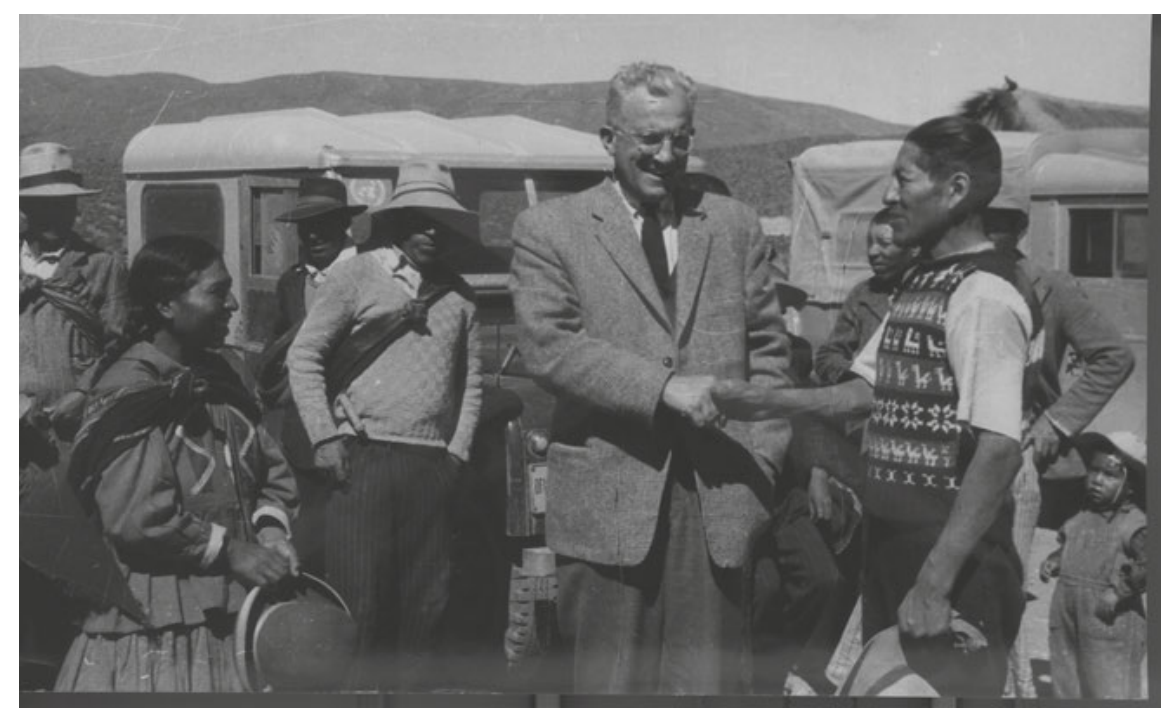

Figure 10: Jef Rens, Deputy Director-General of the ILO, visiting the cooperative in Huana Pasto Grande, Ecuador, in the framework of the Andean Indian programme (AIP).

436 For the report, see ILO, Indigenous Peoples: Living and Working Conditions of Aboriginal Populations in Independent Countries, Studies and Reports, New Series, No. 35 (Geneva: ILO, 1953). 437 Martin Breuer, “Exploring the Technical Assistance Activities of the International Labor Organization in the Field of Indigenous Peoples: Development and Human Rights in the Andean Indian Program (1954-1968)”, Forum for Inter-American Research 11, no. 3 (2018): 110-123. 
Under the leadership of the ILO, the AIP became a laboratory for the "international technocratic class", which had set itself the task of leading "backward" and "underdeveloped societies" into the modern age by using methods of social engineering. ${ }^{438}$ The broad design of the programme, which included questions of nutrition, health, and education, in addition to employment creation and vocational training, reflected not only the specific competencies of the participating international institutions but also the overriding, integrated modernization approach. The bases for action included the installation of ILO projects, such as vocational training centres and productivity programmes, a WHO medical clinic, a UNESCO-run agricultural school, and an agricultural research station led by the FAO. The same integrated approach reappeared in the 1957 Convention, which in its various aspects extended well beyond indigenous labour and included socio-medical, educational, and other aspects of comprehensive modernization. ${ }^{439}$ All action for indigenous populations was, in line with the indigenist spirit of the time, aimed at the integration and ultimately full assimilation of indigenous groups, per se defined as backward and underdeveloped. The treatment of the "indigenous question" reflected the perceived roles of international organizations as "global civilizers" that shaped the first development policy initiatives of the UN system at large. ${ }^{440}$ There was no room for the recognition of cultural diversity or the autonomy of indigenous peoples. Such an understanding would emerge only gradually during the 1970s in the wake of a growing movement towards "indigenous internationalism". ILO discussions reflected this changing approach. It eventually found its expression in the Indigenous and Tribal Peoples Convention (No. 169) of 1989, which removed all the integrationist undertones of the 1957 standard. At the same time, this Convention for the first time introduced the notion of "indigenous people" as a legal term in an international instrument. ${ }^{441}$

The balance for the AIP was mixed, with success and failure about equally distributed. The programme received much praise during its initial phase and, as of 1957, was extended to Argentina, Venezuela, Colombia, and Chile. Around the same time, however, it already began to lose its dynamics. With the progress of decolonization speeding up in Asia and Africa in the late 1950s and early 1960s, the main focus of UN development work gradually shifted to these

438 Guthrie, “The ILO and the International Technocratic Class, 1944-1966”, 115.

439 Indigenous and Tribal Populations Convention, 1957 (No. 107).

440 Dykmann, "Only with the Best Intentions: International Organizations as Global Civilizers". 441 Hagtvedt Vik, "Indigenous Internationalism”. 
regions. In addition, the intended handover of the AIP to the national governments proved difficult. The regionally integrated aspect of the programme was frequently not easy to maintain in the face of economic and political instability, financial problems, and diverging governmental priorities. These factors explain why, although the AIP was one of the most ambitious projects of technical cooperation that the ILO has ever embarked on, it eventually fell into oblivion. ${ }^{442}$

At a different level, however, the AIP had far-reaching implications for the ILO. It consolidated the ILO's reputation in the field of indigenous labour more generally and prepared the ground for its reputation to be one of the leading international institutions in the field to the present day. In retrospect, the AIP, as well as the resulting normative work on indigenous labour, was significant in an even broader sense. It helped to consolidate the position of the ILO as a development agency and reaffirmed the self-perception among the "development politicians" in the Organization, who saw their mandate not limited to the field of vocational training. The way in which the ILO defined its scope of action during the AIP, reaching beyond the ILO's traditional areas of competence into the broader social field, prepared the direction its development work would take during the 1960s.

\section{The World Employment Programme}

When the ILO started to rethink its contribution to development in the early 1960s, it did so in an environment where international debates on the economic progress of the global South had already taken on an increasingly critical tone. The assumptions of early developmental theorists like W. Arthur Lewis that the growth of the "modern" economic sector would be sufficient to create employment and thus absorb labour from the "traditional sector" had proven erroneous. Even in countries where governments were reporting high levels of economic growth, the results were not enough to increase the standard of living by any significant degree for the majority of the population. Projections of unchecked population growth - and of the misery and despair it would create in growing urban conglomerates in Latin America, Asia, and Africa and in the drained rural communities alike - added to the crisis scenario. ${ }^{443}$

442 Breuer, "Exploring the Technical Assistance Activities of the International Labor Organization in the Field of Indigenous Peoples".

443 Unger, International Development. A Post-War History. 
Starting from these observations the ILO began to view its activities in developing countries under a new heading. From the early 1960s onwards, it promoted the creation of "productive employment" as the best way out of the developmental impasse. The World Employment Programme (WEP), launched in 1969 on the occasion of the ILO's 50th anniversary, would become the first culmination of these activities. ${ }^{444}$

In 1961, the ILO published a report on its role in the promotion of economic growth and social progress in developing countries, which was meant to define its contribution to what soon would be announced as the United Nations' first "development decade". ${ }^{445}$ Its key idea was that the social aspects of development, thus far largely ignored, had to take centre stage, in order to save the concept of development itself from being discredited. From the perspective of the ILO, the single most important step was the creation of "productive employment" in developing countries and the inclusion of employment goals as a key element in national development plans. From then onwards, the topic remained constantly on the agenda. A Convention and a Recommendation on employment policy, both adopted in 1964, provided the normative framework for the debate on the shape of a future technical programme. Both standards defined the basic principles and aims of active employment policies, and they were in large parts tailored to the situation in the developing world..$^{446}$ Subsequently, this debate was taken to the regional level, with the so-called Ottawa Plan, emanating from the American Regional Conference of 1966 in the Canadian capital, as the first in a series of regional employment programmes that were intended to form the pillars of a

444 I am very grateful to Michele Sollai, Camille Bolivar, Véronique Plata-Stenger, and Dorothea Hoehtker, who shared with me their rich and not yet published research on the World Employment Programme: Dorothea Hoehtker and Veronique Plata-Stenger, "The Future of Work and Technological Change - the ILO Debate between 1919 and the Early 1980s", unpublished working paper (Geneva: ILO, 2018); Michele Sollai, "Humanizing Development. The International Labour Organisation and the Making of the World Employment Programme (1969-1976)”, unpublished working paper for the ILO Century Project (Geneva: ILO, 2018); Camille Bolivar, "La genèse du World Employment Programme et le projet pilote en Colombie: Un réseau d'experts hétérodoxes pour un gouvernement réformiste”, Master's thesis, Université de Genève, 2017.

445 ILO, The Role of the ILO in the Promotion of Economic Expansion and Social Progress in Developing Countries (Geneva: ILO, 1961).

446 Employment Policy Convention, 1964 (No. 122); Employment Policy Recommendation, 1964 (No. 122). They contained measures to be taken on both the national and international levels and covered areas ranging from investment and income policy, through special methods for creating industrial and agricultural employment, to the implementation of demographic studies. They also reflected the developing countries' view that international agreements on raw materials prices were a precondition for the success of employment policies. 
future worldwide ILO programme. ${ }^{447}$ One year later, Morse presented his plan for a World Employment Programme to the ILC, to be launched on the occasion of the ILO’s 50th anniversary in $1969 .{ }^{448}$

The focus on employment as a means of development had several advantages. Employment policies had been a key topic in the ILO from the beginning, especially at the time of the world economic crisis. They had been high on the agenda at Philadelphia. In addition, they could be easily connected to some of the ILO's previous technical activities, for example the so-called manpower programmes after the war. Despite the fact that employment and manpower policies had so far been mostly associated with industrialized countries, they had also occupied a prominent position with regard to Latin America and influenced parts of the Andean Indian Programme.

It was even more important, however, that the focus on "productive employment" in the global South offered the ILO a way out of an increasingly uneasy position in which it had found itself during the development debates of the early 1960s. Against the backdrop of a widening gap between industrialized and developing countries, some economists started to shift their attention to the biased and "neo-colonial" nature of the world economy, which put the developing countries deliberately and structurally at a disadvantage and made them dependent on others. In the analysis of dependency theorists like Hans Singer and Raul Prebisch, both high-ranking UN officials at the time, the international division of labour and the shifting terms of trade between primary producers and industrialized countries were continuously playing out against the developing countries. At the beginning of the 1960s, their arguments gained increasing currency among developing countries, which soon began to act as a bloc - in particular through the "Group of 77", founded at the first United Nations Conference on Trade and Development (UNCTAD) in Geneva in 1964 - and voiced their demands now more forcefully in all available international fora. As a result, the ILO soon faced com-

447 Under the Ottawa Plan, all the American members agreed to take concerted steps to create more productive employment. The plan's authors saw this as a positive alternative to other measures, such as birth control or forced restrictions on the mobility of the population, which - for political, religious, or administrative reasons - would be difficult to enforce or would take longer to have an impact. Two years later, the Asian Regional Conference in Tokyo launched the Asian Manpower Plan, an adaptation of the Ottawa Plan. At its meeting in Dakar in 1967, the African Advisory Committee also laid the foundations for an African Jobs and Skills Programme, which was finally launched at the third African Regional Conference in Accra in 1969. Alcock, History of the International Labor Organization, 354-360.

448 ILO, Record of Proceedings, International Labour Conference, 51st Session 1967 (Geneva: ILO, 1967), 422-423. 
petitors, such as the recently founded United Nations Industrial Development Organization (UNIDO), which threatened to move into some of its core areas of competence. ${ }^{449}$

The ILO also saw its hands tied with regard to any action that would concern the rules and structures of world trade. Resolutions by African and Asian Regional Conferences, which called on the ILO to broker international agreements guaranteeing price stability for raw materials on the world market, ${ }^{450}$ were met with little sympathy by governments, trade unions, and employers of the industrialized Western countries. Placing the focus on employment, therefore, also served the ILO in initially directing the attention of developing countries away from world trade and to the competences which the ILO potentially had in remedying internal factors of underdevelopment.

The proposal to focus on the creation of "productive employment" has to be seen also in the context of the entanglement between the development debate and the population discourse, which took on an increasingly alarmist overtone during the 1960s. Catastrophic projections of population growth and predictions of the misery that it would entail became bestsellers - such as The Population Bomb by American biologist Paul Ehrlich. ${ }^{451}$ Employment creation was seen as an answer to the threat of uncontrolled urban growth and rural poverty alike, beyond neoMalthusian prescriptions, such as birth control programmes. ${ }^{452}$ This resonated well with member States with a strong Catholic influence, especially in Latin America. Accordingly, the Ottawa Plan had put special emphasis on this aspect. ${ }^{453}$

Last but not least, the WEP cannot be seen in isolation from a general trend towards large global campaigns, which almost all parts of the UN system followed in the 1960s. These campaigns were encouraged by new sources of development funding available through the UNDP, which gave a strong incentive to

449 Alcock, History of the International Labor Organization, 343-346.

450 Resolution concerning the Stability of World Commodity Markets and Their Influence on Levels of Living and Employment, African Regional Conference (AFRC) I (1960), Record of Proceedings, Appendix VI: Resolutions and Conclusions Adopted by the Conference, 280-281; Resolution concerning Measures to Promote Stable Prices of Basic Commodities in World Markets and other Measures for the Effective Utilisation of Resources and the Improvement of Living Standards, Asian Regional Conference V (1962), Record of Proceedings, Appendix VII, Resolutions and Observations Adopted by the Conference.

451 Paul R. Ehrlich, The Population Bomb (New York: Ballantine Books, 1968).

452 Thomas Robertson, The Malthusian Moment: Global Population Growth and the Birth of American Environmentalism, Studies in Modern Science, Technology, and the Environment (New Brunswick, NJ: Rutgers University Press, 2012).

453 For an overview, see Alison Bashford, "Population, Geopolitics, and International Organizations in the Mid-Twentieth Century", Journal of World History 19, no. 3 (2008): 327-348. 


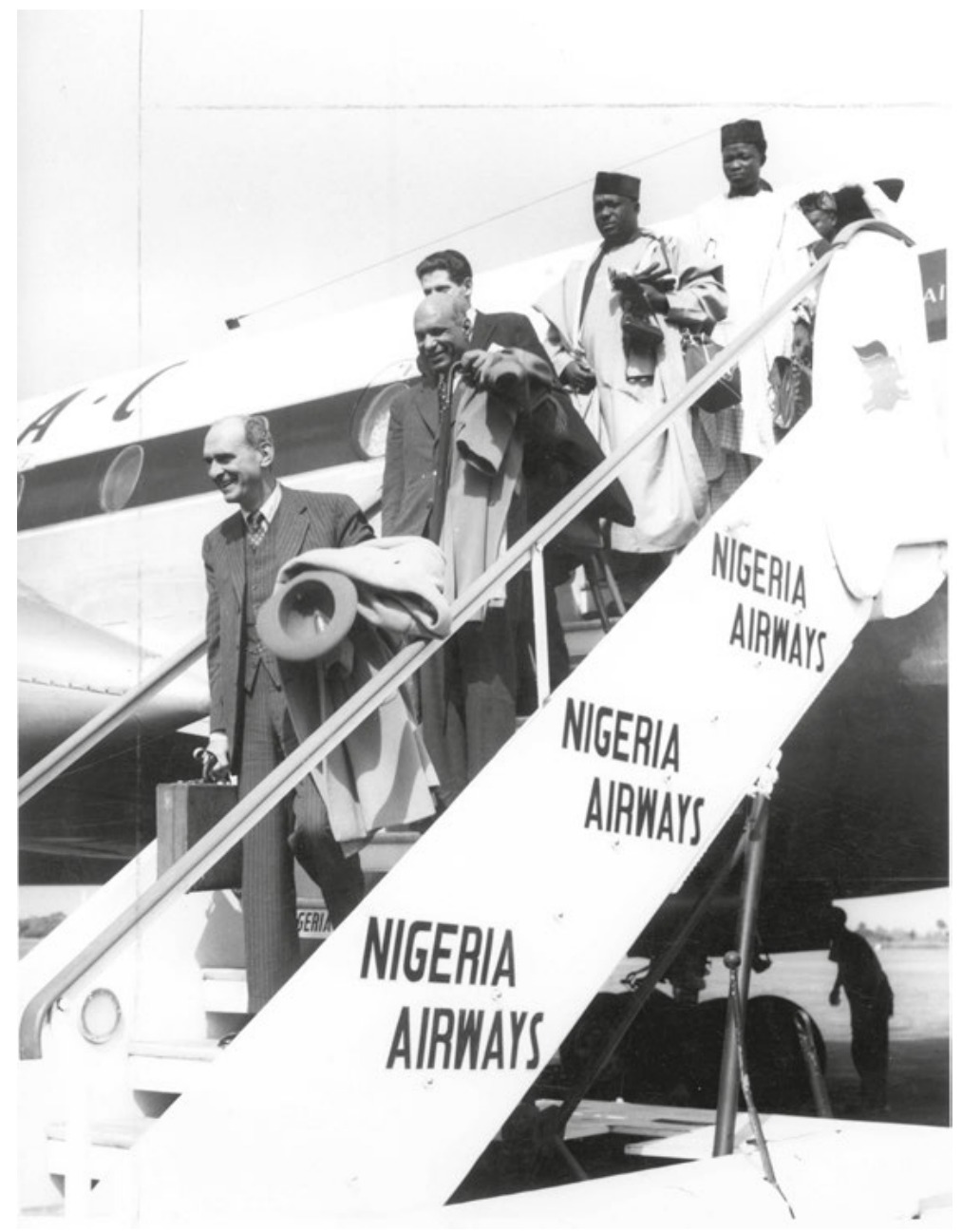

Figure 11: ILO Director-General David Morse arriving to the First African Regional Conference, Lagos, Nigeria, 1960.

international agencies to both launch large size programmes and get involved more directly in the developing countries' planning processes. Campaign-style programmes were also in line with new techniques tested by international agencies to reach out to a broader international public through cooperation with NGOs and academic partners. The WEP has to be seen in the context of a whole series of similar campaigns taking off from within the United Nations system during the 1960s and 1970s. Examples are the FAO's Freedom from Hunger Campaign 
(launched in 1960), UNESCO's Experimental World Literacy Programme (1967), and the WHO's Global Eradication of Smallpox Programme (1967). ${ }^{454}$

Once the WEP had started with developing regional employment plans, the actual programme was supposed to consist of a research and an implementation phase. In 1969, Morse put his Egyptian Deputy Director Abbas Ammar in charge of the programme. He then entrusted the operational planning to Hans Singer, who had just ended his latest United Nations assignment as Director of Research at UNIDO, and to Walter Galenson, an American labour economist who, since 1968, had counselled the Director-General on the economic aspects of the WEP. For the research work, the ILO obtained the cooperation of the leading developmental economists in those years, including W. Arthur Lewis and Jan Tinbergen. The key part, however, fell to the Sussex-based Institute for Development Studies (IDS) and its head, Dudley Seers. Their role in the context of the WEP was significant, as it had been Seers and his colleagues who in the 1960s had formulated the most coherent counter-position to the growth-centred orthodoxy of Lewis and the first generation of developmental economists. The IDS, under Seers, went beyond the aim of economic growth and shifted the focus instead to poverty as the main obstacle of economic progress. The Institute argued in favour of social policy measures and redistributive action as a way to put economic development back on track. These positions became prominent through research conducted by the WEP, but, even more importantly, they had an impact through the participation of Seers and other IDS scholars in highly publicized pilot country missions that would form the heart of the WEP's initial phase. ${ }^{455}$

The first of the pilot missions, led by Seers to Colombia in 1970, already set the tone for the expansive approach the WEP would take. Its final report, Towards Full Employment: A Programme for Colombia ${ }^{456}$ was regarded a "major breakthrough in development thinking" because of the "complete look at the problem of employment" in relation to a whole set of other economic and social factors like land tenure, income distribution, and international trade. ${ }^{457}$ The report argued that income inequality should be treated as a cause, and not as an effect,

454 Frey, Kunkel, and Unger, "Introduction: International Organizations, Global Development, and the Making of the Contemporary World"; Kevin O'Sullivan, "A Global Nervous System: The Rise and Rise of European Humanitarian NGOs", in International Organizations and Development, ed. Frey, Kunkel, and Unger, 196-219.

455 For a summary of the research output, see Hans Singer, Research of the World Employment Programme: Future Priorities and Selective Assessment (Geneva: ILO, 1992).

456 Towards Full Employment: A Programme for Colombia Prepared by an Inter-Agency Team Organised by the ILO (Geneva: ILO, 1970).

457 Sollai, “Humanizing Development”, 13. 
of unemployment. To overcome it, a comprehensive set of measures was needed. These included land reform, the redistribution of wealth through taxation, and a foreign exchange policy that favoured the growth of export-oriented industries. The reduction of poverty, attention to the rural sector, and the implementation of redistributive measures were seen by the report as the main ways to create employment. ${ }^{458}$

The Colombia report received wide acknowledgement within the United Nations, and this paved the way for all the future WEP missions. Of the three missions that followed - to Sri Lanka, Iran, and Kenya - the last one, in particular, contributed to the WEP's legacy. The Kenya mission of 1972 was conducted by Hans Singer together with a number of his IDS colleagues, who were accompanied by the new head of the WEP, the Dutch economist Louis Emmerij. It was carried out with the same broad conceptual approach as the Colombia mission, and it, too, focused on the problem of poverty as the single most important obstacle to development. ${ }^{459}$

The lasting legacy of the Kenya mission was mainly due to the establishment of two central terms in Singer's report, which was published under the programmatic title Employment, Incomes, and Equality. ${ }^{460}$ It called for a "redistribution from growth" to fund investments in order to improve productivity and raise the incomes of the poorest sections of the population. At the same time, Singer emphasized the strategic importance of the so-called informal sector of the economy. His report elevated the informal sector, in its many different facets, from its status as a simple marker for underdevelopment and stagnation to the central role of a dynamic - if not the most dynamic - element of developing economies. $^{461}$

Together with the research conducted by the WEP in the first half of the 1970s, the Columbia, Kenya, and Sri Lanka reports helped to establish a new focus in development thinking that, for the first time, centred on the problem of poverty. The innovative approach and the easy-to-understand central postulates of the reports helped to calm whatever criticisms there was of the WEP's increas-

458 Bolivar, "La genèse du World Employment Programme”, 10-15.

459 Sollai, "Humanizing Development”, 15-20.

460 ILO, Employment, Incomes, and Equality: A Strategy for Increasing Productive Employment in Kenya (Geneva: ILO, 1972).

461 The term "informal sector" was originally introduced at the IDS by the anthropologist Keith Hart in 1971, but it was first used in a publication by Hans Singer. See Aaron Benanav, "The Origins of Informality: The ILO at the Limit of the Concept of Unemployment”, Journal of Global History 14, no. 1 (2019): 107-125. For an overview, see Paul E. Bangasser, The ILO and the Informal Sector: An Institutional History, ILO Employment Paper 2000/9 (Geneva: ILO, 2000). 
ingly expansive drive. The success of the pilot missions cast a favourable light on the WEP. It also helped to distract from the fact that, in almost all of its aspects, the programme had distanced itself from its originally planned set-up. The WEP had been conceived as a cross-departmental undertaking that would engage all sections of the International Labour Office. As it developed, it was instead run by a small group of staff within the ILO, with only a slight connection to the ILO's daily work, and a group of outside consultants, most of which were affiliated with the IDS. While the ILO's Regional Offices were supposed to play a key part in the implementation of the programme, the WEP had quickly turned into a highly centralized undertaking managed from the Geneva headquarters.

The same was true for the intended cooperation with other UN agencies, which never materialized on the ground. And finally, while it had always been a declared aim to include in the programme all social aspects related to the overarching goal of creating "productive employment”, the ILO assurances to other UN agencies that it would not intrude in their core areas of competence became obsolete after the publication of the first mission reports. The WEP existed mainly outside of the ILO's regular structures, and it was financed mostly through the contributions of single governments like Denmark, the Netherlands and Sweden. ${ }^{462}$

The WEP drew criticism from many quarters. Some of the officials at the International Labour Office felt that the programme was too detached from the rest of the Organization's work, and many of the ILO's constituents shared those views. Trade unions resented the fact that the WEP escaped oversight by tripartite bodies, which the programme itself did not set up on the ground. The Employers' and Workers' groups were also generally critical of the focus on the informal economy. They were alarmed, especially after the first pilot country mission to Colombia had left them out of the projected activities. ${ }^{463}$ The employers and some governments, particularly the United States, were not too keen on the priority that the WEP gave to economic planning and state-directed redistribution strategies. The same was true for some of the recipient countries, whose political leadership all too often showed little sympathy for forceful calls for redistribution and land reform. Colombia, which had hosted the first pilot project, was an exception in this regard, since its President, Carlos Lleras Restrepo, had invited the WEP mission for the express purpose of winning external support and legitimacy for his plans for comprehensive land reform. ${ }^{464}$ In Kenya, by contrast, the government quickly shelved the proposals of the Singer mission. ${ }^{465}$ The elite-centred

462 Sollai, “Humanizing Development”, 21.

463 Ibid.

464 Bolivar, "La genèse du World Employment Programme”.

465 Ibid. 
approach of the WEP and a certain naiveté (or even arrogance) regarding the role of post-colonial elites as willing executors of the programme proposals - which the missions and the reports took for granted - led to a different kind of criticism of the WEP from the political left. ${ }^{466}$

Despite or even because of these circumstances, the WEP was (and could still be seen as) a success story for the ILO. This had less to do with the actual impact of the WEP on the employment situation in the developing countries, which would have been hard to measure in any case. What the WEP achieved, however, was to contribute significantly to a shift in the development discourse of the 1970s. Its concern with poverty as a prime obstacle to development also served as an inspiration to the UN system in general. As an alternative to the traditional insistence on economic growth and the gross national product (GNP) as the prime yardstick of development in the global South, ${ }^{467}$ it offered the possibility of a fresh start under a new paradigm. Through the WEP, however short-lived its heyday would prove to be, the ILO took a decisive step towards gaining recognition as an international development agency. The WEP encouraged an impressive body of research by highly renowned scholars such as Amartya Sen. It left a rich research legacy in fields ranging from population growth, rural development, to urbanization, trade, education, automation, migration, the environment, and the use of “appropriate technology". ${ }^{468}$

The World Employment Conference in 1976 and its final report on "Employment, Growth, and Basic Needs: A One World Problem” was the high point of the WEP. ${ }^{469}$ What its authors, Louis Emmerij, and his successor as Director of the WEP Research Section, the Kenyan Dharam Ghai, proposed was the creation of employment by a combination of poverty reduction and redistributive measures, such as taxation or land reform. "Basic needs", the key term of the report, included aspects of food security, housing, essential services in health care, sanitation, education, and public transport. These were seen as an essential precondition of employment policies. Its authors did not invent the notion of "basic needs", but they greatly helped to popularize the term. Over the following

466 Chris Gerry, “The Theoretical Basis of the World Employment Programme: A Note on Pragmatism, Social Democracy and Ideology”, Manpower and Employment Research 10, no. 2 (1977): 25-31. 467 For a discussion on the GNP and growth-centred paradigm in a broader perspective, see Matthias Schmelzer, The Hegemony of Growth: The OECD and the Making of the Economic Growth Paradigm (Cambridge: Cambridge University Press, 2016).

468 Bangasser, The ILO and the Informal Sector.

469 ILO, "Employment, Growth and Basic Needs: A one-World Problem". Report by the DirectorGeneral of the International Labour Office. Tripartite World Conference on Employment, Income Distribution, and Social Progress and the International Division of Labour (Geneva: ILO, 1976). 
years, the United Nations, the World Bank, and several other international and national agencies, such as the United States Agency for International Development (USAID), adopted the concept for a short while. ${ }^{470}$

However, the World Employment Conference not only marked the take-off of the basic needs concept. It also was the WEP's swan song and the beginning of its slow decline. The oil crises of the 1970s, which hit the majority of developing countries much harder than the industrialized West, had by then already shattered the hopes for the realization of the programme's most ambitious goals. At the same time, many developing countries had all along been critical of calls for a "dethronement of the GNP" 471 and the emphasis on basic needs. Against the background of discussions on the New International Economic Order (NIEO), proclaimed by the UN General Assembly in 1974, they feared that the WEP was steering the debate away from the most fundamental issue, the unfair global trade order. Many leaders of countries in the global South also were hesitant, to say the least, to fully embrace the redistributive aspects of the WEP for internal political reasons. $^{472}$

In any case, when basic needs caught on in the World Bank under its President, Robert McNamara, and elsewhere in the UN system, a new paradigm shift in development thinking was already on the horizon. Despite all discussions on the NIEO, little had happened. Many countries, on the contrary, faced massive debt crises. Thus, the tide gradually began to turn, and international institutions became part of this development. During the 1980s, under the influence of an all-out attack on Keynesian economics - which seemingly had not been able to provide solutions for the economic crises - poverty-centred approaches to devel-

470 The term "basic needs" had been first used in the 1940s by the renowned psychologist Abraham Maslow and had been picked up by the Bariloche Foundation in 1975.

471 Obviously, the WEP was not inimical to growth as such; according to Louis Emmerij, a 6\% growth was the target. See Guy Standing, “The ILO: An Agency for Globalization?”, Development and Change 39, no. 3 (2008): 355-384, esp. 362. Morse had used the expression "dethronement of the GNP" upon leaving the post as Director-General 1970 to pinpoint the shift of emphasis. The citation of the Morse article is taken from: David A. Morse, "The Employment Problem in Developing Countries", in Prospects for Employment Opportunities in the Nineteen Seventies. Papers and Impressions of the Seventh Cambridge Conference on Development Problems 13th to 24th September 1970 at Jesus College, Cambridge, ed. Ronald Robinson and Peter Johnston, 5-13 (Foreign and Commonwealth Office, Overseas Development Administration, Cambridge University Overseas Studies Committee, London, HMSO).

472 The discussions on the NIEO are covered in a broader context by Christopher R. W. Dietrich, Oil Revolution: Sovereign Rights and the Economic Culture of Decolonization, 1945 to 1979, Global and International History (Cambridge: Cambridge University Press, 2017). 
opment gave way to structural adjustment programmes that reversed much of the preceding decade's emphasis on social development. ${ }^{473}$

For the World Bank, which had from the start downplayed the role of "redistribution from growth" in its version of basic needs, it was only a small step toward using the concept as an alternative to redistributive measures, both at the local and global levels. ${ }^{474}$ Rather than a means to lift up the poor, basic needs became a mere modicum of structural adjustment and an excuse for not addressing the structural causes of increasing inequality. Under the neoliberal paradigm, the informal economy turned from a springboard for the creation of productive employment to a pool of entrepreneurial energies. ${ }^{475}$ Against this backdrop, the WEP, once promoted as the carrier of a new concept of "development with a human face", ${ }^{476}$ slowly fell into oblivion and faded out on the institutional level until it was wrapped up in the mid-1990s. ${ }^{477}$

473 An overview and critical assessment of the Washington Consensus and structural adjustment after two decades is provided in Narcís Serra and Joseph E. Stiglitz, The Washington Consensus Reconsidered: Towards a New Global Governance, The Initiative for Policy Dialogue Series (Oxford: Oxford University Press, 2008).

474 Rob Konkel, "The Monetization of Global Poverty: The Concept of Poverty in World Bank History, 1944-90”, Journal of Global History 9 (2014): 276-300.

475 John Toye, Dilemmas of Development: Reflections on the Counter-Revolution in Development Economics, 2nd ed. (Cambridge, MA: Blackwell, 1993).

476 Santosh Mehrotra and Richard Jolly, eds., Development with a Human Face: Experiences in Social Achievement and Economic Growth (Oxford: Oxford University Press, 1998).

477 Research continued throughout the 1980s, as did regional programmes, such as the Regional Employment Programme for Latin America and the Caribbean (PREALC), the Jobs and Skills Programme for Africa (JASPA), the Asian regional team for Employment Promotion (ARTEP). See Gerry Rodgers, ed., The Poverty Agenda and the ILO. Issues for Research and Action (Geneva: International Institute for Labour Studies, 1995). 
